College, which gives us the fruits of his long experience and knowledge.

In the introductory chapter Col. Melville en phasises the necessity of subordination to the exigencies of the coinmander. He most ably points out how the responsibility rests with the commander, and if that officer decides that he can best defeat the enemy by losing men by overmarching, it is not the place of the principal medical officer to harass him with protests. This chapter contains most sound alvice which must be carefully studied by all medical officers who desire absence of friction with the executive.

Most excellent detailed treatment of the question of recruiting, physical training, and marching are next dealt with. The amount of water needed on the march is very definitely laid down. In the chapter on Diet the anthor disagrees, as most practical men do, with Chittenden's conclusion and also protests against monotony in diet. In the chapter on Waste destruction, Col. Melville is half-hearted in recommending incinerators. In our experience the objections which be enumerates are generally the result of faulty construction chiefly insufficient chimmey height and consequent failure of draught. In the chapter on Malaria Prophylaxis the importance of removal to a distance of native bazurs is omitted. The numerous children in these bazars are generally the source of infection.

The book is one of the most important that has ever been written on the subject, and no medical officer with troops can afford to be without it. We hope to see many editions keeping pace with the progress of the science.

\section{The Bacteriology of Surface Waters in the}

Tropics.-By MaJor W. W. Clemesha, M.D., D.P.H., Sanitary Commissioner, Bengal. Thacker, Spink \& Co., Calcutta. Rs. 7-8.

This is a scientific monograph giving the results obtained by the author and his assistants in a very large series of experiments carried out in Madras and Bengal. It deals with a highly technical and difficult subject on which the author is a past master and the book will become a standard work of reference.

The main conclusion arrived at is that in the tropics we cannot rest content with demonstrating the "true coli group" of Houston and Savage nor condemn waters containing them. The author shows that further analysis of the species included in this group is of the greatest importance, each member of the group having a special significance. Moreover some bacilli not included in Houston's true coli, such as Oxytoccus perniciosus, are in the tropics a certain indicator of objectionable contamination.

'There is a certain amount of controversial matter which the English experts may attack. Every worker in the tropics must make an intimate study of Major Clemesha's findings.
A Practical Text-book of the Diseases of women.-By Arthur H. N. Lewers, M.D., F.R.c.P. Seventh Edition. Illustrated. H. K. Lewis, London, 1912. Price 12s. 6d.

J'His well-known and highly-appreciated text-book has been a favourite with students and qualified medical men for a large number of years. The present edition has been considerably enlarged and much new matter added in various parts of the book, and the whole has been thoroughly revised. The section on cancer of the uterus and that on fibroid tumnours have been amplified. A large number of additional illustrations appear also sereral micro-photographs. We can only repeat our appreciation of former editions of this important work, an appreciation that has received ample endorsement from the profession as the necessity for seven editions would demonstrate. We would particularly bring it to the notice of senior students attending the gynæcological wards of hospital.

A Cyclopædia of American Medical Biogra. phy, comprising the lives of eminont deceased Physicians and Surgeons, from 1610 to 1910.-By Howard A. Kelly, M.D. Illustrated with Portraits in two volumes of 969 pages. Messrs. W. B. Saunders Co. Cloth. 42/net.

These tivo volumes have required five years of careful study and research for their compilation. In them the author's aim has been to give a brief outline of the life of every medical worthy who has lived in the United States and in Canada - men who were distinguished, either as original thinkers, teachers or as leaders in medicine in any part of the country. By the conjoint labours of a large number of able condjutors, upwards of twelve hundreal worthies have been gathered in to this Hall of Fame.

'Those who have acquaintance with Professor Kelly's work on abdominal surgery will find the present volumes quite up to the high standard therein set up; and the very large number of medical officers in India, who have the cultivated man's desire for literature and a knowledge of the lives and writings of distinguished members of the profession, will be charmed with the material afforded for further study.

'The work will be found of great advantage as a book of reference and its value is considerably enhanced by the beautiful illustrations and the splendid manner in which the publishers have done their share of the work. It is a cyclopredia that should be in every library and on the bookshelf of all those who are interested in the lives of the founders of medical knowledge.

Preventable Cancer : a Statistical Research. -By Rollo Russell. Messrs. Longmans, Green \& Co, London, 1912. Price 4/6.

THE author has collected a very great deal of information bearing on the conditions that 